\author{
NIKOLA MLAĐENOVIĆ \\ Faculty of Political Sciences, University of Belgrade, Serbia \\ NMLADJENOVIC@YAHOO.COM \\ ORCID: HTTPS:/ / ORCID.ORG/0000-0001-8724-4363
}

\title{
The Bias of Mediatization: Utopia in Charlottesville
}

\begin{abstract}
The paper reconstructs Harold Innis' idea of media's bias. It is argued that media construct a view of the future in line with temporalized Platonism that excludes people that belong to the past. The clash of statues and media in Charlottesville presented mediatization as a progressive but not dialectical force. Statues and media did not check each other's biases. Media embody the confrontation of authority and publicity (Habermas) or the Enlightenment and Absolutism (Koselleck). After the neoliberal commercialization, the Enlightenment acquired the form of utopian future that confronts the media logic against conservative forces. The truth is constructed according to the prescribed future. Trump blamed all, in accordance with the Absolutist principle. Commercial media professionalism stood by its Enlightenment origins and accused Trump of revitalizing forces of the past. Because most citizens were against taking down the statues, commercialized media logic was less receiver steering than the public service media.
\end{abstract}

Keywords: mediatization; neoliberalism; populism, bias of communication; Donald Trump

\section{The counterrevolution}

While arguing that populism is a cultural backlash against post-materialistic values, Ronald Inglehart and Pippa Norris (2016) paraphrased Herbert Marcuse by saying populism is a "counterrevolutionary revolt". But this had a materialistic, anti-capitalist meaning in the Nixon era. For Marcuse (1969, p. 65) mass media "speak day and night for the dominant interests" and "radical Left has no equal access to the great chains of information and indoctrination" (Marcuse 1972, p. 55). James Curran (2011, p. 32) states that counterculture's anti-war effort was mostly reported "in terms of the threat it posed to public order/military morale and the deviant life style" and there was only a "constrained, elite-driven way" of critique. Noam Chomsky (1989, p. 227) supported Marcusean views years later: "the media were almost entirely closed to principled critics of the war and representatives of the mass popular movements 
that spontaneously developed, considerably more closed, in fact, than they have been in the 1980".

Chomsky's view that the 1980s were better than sixties or seventies can help us to understand why Inglehart and Norris tried to act as Marcuseans themselves. Marcuse (1972, p. 24) said that "freedom of expression hardly exists for the blacks", whereas the case of Donald Trump in general and Charlottesville in particular point to a huge media change in contemporary societies. Media were not closed to African Americans and their popular movement, and the Confederate side was presented as the deviant one. Whether that means that media now do not speak for the dominant interests is, I am afraid, a different matter.

What happened between the two "counterrevolutions"? A change in the neoliberal hegemony is as striking as the media change. Counterculture for Friedrich Hayek (1998, p. 174) was a product of "non-domesticated savages" that refused the "burden of culture" and could not tell the difference between good and evil. Things were worse for African Americans. Milton Friedman (1982, p. 112) maintained that hiring "white clerks in preference to Negroes" is not a prejudice, but "transmitting the tastes of the community". Alexander Rüstow (1980, p. 40) had a theory that slavery lasted so long because "Negroes from Africa (...) living in archaic superstratified empires, had for years been bred and raised to be submissive". This is what neoliberals were saying for decades.

Now, neoliberals seem progressive and countercultural. They are not the bearers of "the whole complex of aggression and targets [that] indicates a proto-fascist potential par excellence" (Marcuse 1972, p. 28). The Democrats embraced this ideology as early as Carter administration and until Bernie Sanders it remained undisputed. Corporate media are somehow supportive of the Black Lives Matter. This paradoxical co-evolution of neoliberalism and mediatization is the background of the special bias of mediatization. Is it possible that racial games in the USA can actually help further neoliberalization, even though original neoliberals were not very keen on the counterculture and African Americans? And is it possible this kind of mediatization is not the best way to fight populism?

In this paper I will try to show the nature of the relationship between mediatization and populism. Through interdisciplinary critical framework I will relate social to discourse structures (van Dijk 2018, p. 27) and present the "capitalist character" of the "power behind discourse" (Fairclough 2018, p. 14). My overall approach is thoroughly influenced by Frankfurt School's tradition. In the next section, I will use Habermas' and Koselleck's theories to deconstruct mediatization and discuss the neglected element - interplay. In line with the critical perspective, this will help to show the corporate background of the media structure that shapes ideological and socio-political configuration of messages. In the third section, I will refer to Innis and Koselleck in order to question media's time bias and its logic of Enlightenment. Time bias is a matter of collective identity. It drives society's relationship with past and future. 
To check this theoretical framework, I will examine the case of clashes over Confederate statue in Charlottesville, that is, a struggle between old, heavy media and the light ones. I will use multiperspectival interpretative method (Kellner 1995) and frame analysis (de Vreese 2014). Today's political conflict over American identity was at its most regressive in clashes between activists that wanted to bring down or keep the statue of a Confederate commander. Conflict embodied a political polarization in contemporary America between conservative and progressive forces. Monuments are the oldest medium with a conservative time bias, that in Charlottesville was confronted with a light, electronic media with a future-oriented bias. This case showed the bias of mediatization that is a matter not just of social construction but of political economy.

\section{The interplay}

Mediatization denotes the interplay between media-communicative change and socio-cultural change. Unfortunately, this is usually understood as a theory of media influence on the society, not the interplay as such. What is specific about mediatization is certainly the analysis of the power of media-communicative change, but that is not what is pertinent. Mediatization could contribute to social theory (Couldry 2014) only if the focus is on the dialectic of reciprocities between the media and the society (Hepp 2013, p. 44). The interplay of media's and state's meta-capital, or the interplay of different meta-processes, is something that critical theory should be concerned about. Media's meta-capital is constructed within a social structure marked by neoliberal globalization meta-process. The roll-back of the welfare state and media commercialization are not just parallel but complementary processes. Although rising inequality and austerity policies created the conditions for a populist reaction, this is rarely sufficiently acknowledged. When it comes to media populism as a "nexus of influences" between media logic and populism (Mazzoleni 2014, p. 47), the problem is still the interplay: "media logic and media populism appear to be somewhat overlapping concepts" (p. 48). And what is the actual connection between phenomenon of populism and media logic?

This problem is understandable at the start of a great tradition, that I believe mediatization will become. It is asking the right questions, but if it is going to be an interdisciplinary approach then it should not examine the interplay from mediacentric perspective. It should actually become a social theory. Mediatization is a contextually sensitive process (Peruško 2017), therefore, we need to theorize this context, the whole interplay, in order to understand mediatization and its role in the society. One way to do it is to examine what social thinkers call mediatization. Jürgen Habermas (1989, p. 27) defined it as a "mode of balancing power", like in the "demarcation of estate liberties from the prince's overlordship". Mediatization was a way to establish some boundaries between the monarch on one side and bourgeois and aristocra- 
cy on the other side, to "mediatize" the power within society. After late capitalism brought the fragmentation into special-interest parties, the "mediatized public" (p. 177) produced not critical but "manipulative publicity" (p. 178) with an intent to "neutralize political counterpressure" (p. 200). A mode of balancing became a mode of colonization.

Reinhart Koselleck (1988, p. 39) provided a different view: "mediatising the ecclesiastical conflicts" implied neutralizing those conflictual discourses that constantly lead to "civil war". In Charlottesville's case, it would call for "moral neutrality" and suspension of the moral conflicts by the "sovereign decision" (p. 38). Kosseleck reminds us that, unlike aristocracy, the goal of bourgeois was not to create a balance of political and economic power. The bourgeois did not seek a peaceful arrangement with the monarch. Not a balance of power, but a conflictual discourse against Absolutism and for the Republic was essentially a moral argument for a total social change. Instead of suspending the moral conflicts, the bourgeois reintroduced them in order to benefit from permanent civil conflict. For Kosseleck it is the sovereign state that is mediatizing struggles, suspending the conflictual discourses in order to reach peace. Commercial media were mediatizing a revolution.

Of course, both examples are not what is ordinarily understood as mediatization. They are closer to the idea of social mediation, but they are important if we concentrate on the interplay. Habermas' (1989, p. 73) mediatization implies a tension between authority and publicity, the "disproportion of economic power and political powerlessness" (p. 69). It is a "political confrontation (...) against the public authorities themselves, to engage them in a debate over the general rules" in the "sphere of commodity exchange and social labour" (p. 27). Commercial media, therefore, play a special role in determining the social and market rules. On the other hand, Koselleck understands this as a confrontation of the principles of Enlightenment and Absolutism. But it is a whole different matter when commercialization and the Enlightenment are on the same, neoliberal side. In Hegelian terms, they are "a powerful bloc in opposition to the organized state" (Habermas 1989, p. 119). The monarch is merely human, "and as a man he could be nothing but a usurper (...) a brutal tyrant" (Koselleck 1988, p. 119). Quotes describing $18^{\text {th }}$-century France sound so familiar in the Trump era.

If the first consequence of neoliberal mediatization was marketization of society by proclaiming the value of economic freedom, the second problem was connected to this in a way that now every social relation is seen only as a form of competition. Marcuse (1991, p. 92) teaches us every society is marked by contradictions, but one-dimensional society embraces the "principle of the logic of manipulation - realistic caricature of dialectics". This fake society has to produce fake news. That is, constant conflicts without resolution. Media fail to reconcile conflicted parties not just because its logic is one of dramatization and emotionalization, but because this logic is a product of neoliberal competitive discourse. Frame of conflict reigns. Commercialized media cannot accept what Axel Honneth (1995, p. 23) sees as a special dimension of social 
conflicts, their "moral-practical potential for learning", for deliberation that can create "an interpretative framework for a process of moral formation" (p. 168). Balance of power is not a goal. It can only be endless war.

\section{Time of the Utopia}

Time is a "relationship between past and future" (Koselleck 2002, p. 111). Without some perspective on time we are practically humans with banal nationalisms or religions. This is Marcuse's (1991, p. 100) message to one-dimensional societies: the second dimension is "historical"; it discovers "potentiality as historical possibility". In this context, Innis' idea can be understood for what it is. "The bias of communication in space or in time involves a sponge theory of the distribution of wealth" (Innis 2008, p. 76). No technodeterminism in sight. The cultural "bias of significance" (p. 33) depends on medium's emphasis on knowledge dissemination over time or space, but it is not just a matter of media's materiality but of political economy. Society's collective identity is based on the relationship between past and future, but time bias also depends on the distribution of wealth. For Innis, medium's time bias (e.g. monuments) refers to religion, tradition and decentralized society (p. 36), while space bias of the "light media" is connected to the growth of trade, industry, administration and the rise of the vernacular, which facilitated the creation of Protestantism and critical press (p. 58). How is this connected to the political economy?

There is constant debate on how we can understand today's problem of populism. For most, it is a struggle between populism and liberal democracy. But for classical liberalism the state and the market were confronted. The market actors requested the implementation of the laissez-faire principle, so that the market does not get disturbed; the state was concerned that economy benefits all. That tension is gone in neoliberalism - it is the state that has a primary goal of creating, facilitating and maintaining the market. The state and the market are closely interconnected (Balibar 2015, p. 103). It is possible even to do away with democracy. Neoliberals are ready, if the order of the free market is in any way threatened, to "temporarily suspend" the "principle of the free society" (Hayek 1998, p. 124). The sovereign has to be able to introduce the state of emergency (e.g. Trump's wall) to preserve the order. Hayek does not have a problem with "abolishing democracy (...) in defense of economic freedom" (Streeck 2011, p. 7). Actually, along with Friedman, Hayek supported exactly that in Pinochet's Chile.

Today's struggle of populism and neoliberalism should be understood as a regressive conflict between democracy and liberty (Bonefeld 2017, p. 15), a struggle between their degenerated forms. From a political economy perspective, it is also a tension between the national and transnational capital (Močnik 2017). Donald Trump, along with Breitbart and the business class that did not globalize its assets, belong to the national capital's side. Hillary Clinton, transnational media corporations such as Am- 
azon or Facebook, belong to the other side. The conflict looks pretty clear. When it comes to news media, it is a tension between Breitbart and, for example, Washington Post, owned by Amazon's CEO. When it comes to big data problem, the tension is between Cambridge Analytica and Facebook, Google, or any other transnational company related to this issue. It is about interests, not values, because they are all, Democrats and Republicans - neoliberals (Habermas 2012, p. 104). Therefore, it is always a story about the distribution of wealth, but within capital itself - it is not a capital vs. labour struggle. If we fail to relate this social structure to media discourses, critical examination will not be possible.

With this in mind we can turn back to Innis' idea of time bias. He believed French Revolution could be explained only by taking wealth into consideration. If one actor accumulates too much wealth, others will attack its monopoly over time. In the case of absolute monarchy, those actors for Innis were church and the state (2008, p. 76), as time and space bias entities. Church is closer to the heavy media and the state is more secular, light media oriented. But were they actually the ones who accumulated too much wealth? This is different than Habermas' account of political powerlessness of the state against the rising bourgeois, or Koselleck's view of Absolutism's collapse. Although we can agree with Innis' "sponge theory", it is doubtful whether his explanation of the revolution is entirely correct. Nevertheless, his description of modern capitalist age shows the triumph of certain banal Enlightenment, where sense of time was destroyed by commercialism, and that "fascism, communism and our way of life" (p. 88) were a reaction to this. Light media were the commercial ones, on the side of the bourgeois in the Habermasian political confrontation between authority and publicity. Commercial media were producing a worldview in line with the market actors' ideology.

On the other hand, it is interesting Innis does not consider progress as a form of time but as perpetual movement and a category of space monopoly. Maybe his original understanding of time was too conservative. It had no relationship to the future. For Koselleck, enlightened philosophers had more to offer. Utopia, an imagined social perfection, is not placed in a foreign space anymore but in a foreign time. The "perfectio ideal" (Koselleck 2002, p. 90) was temporalized. A promise of the new world brought simultaneous denying of the old, and because this doctrine was a moral one, reality was "not only incomplete, limited, or unstable but also immoral" (Koselleck 1988, p. 152). It is considered immoral even without Trump. It is immoral because it is not suited for the desired future. It is possible to differentiate values and social relations that should be overcome, that have no place in the future projections of a certain victory of the Enlightenment. The Enlightenment served just one side of the political confrontation, which is today a transnational capital's side. "Doomsday" (p. 182) is reserved for the people of the past and their collective identity: nationalists and alt-right, while the progressive humankind awaits a space biased utopia as "a politically unsecured loan (...) being called in" (p. 186). Absolutist domination over all 
subjects and the neutralization of conflictual discourses within the civil society (e.g. the role of the President) are unacceptable relics that have no place in the future. This is a completely different, even provocative view of the progress, because Koselleck sees Absolutism as a guarantee of peace that suspended the ecclesiastical conflicts of Protestants and Catholics, and after its fall new social conflicts appeared.

Absolutism was advocating a frozen, completely static state, while the Enlightenment was a progressive doctrine. Its goal was to "write of the past and create its substance out of the future" (Koselleck 2004, p. 54). Once this future utopia became central, "expectations have moved from all previous experiences" (Koselleck 2002, p. 128). New ideologies like liberalism or socialism, even fascism, had "no content in terms of experience" (p. 29). This position allowed Koselleck to represent the Enlightenment as "the violence of spirit and reason, a violence that eradicates all violence" (p. 91), an excuse for the attack on everything conservative. Conservative being, of course, when you want to make something great again. This "great again" implies a past condition, and Trump does not want to conserve it, because he has to construct it again. It is a lost past that has to be re-made, according to the national capital's interests and its time bias. On the other hand, transnational capital and its commercial media want to stop this process. The Enlightenment, this "subjectively pure will to peace" apparently has war-like characteristics that can lead to "bellum omnium contra omnes" (Koselleck 1988, p. 28), because its vision of the peace is excluding the losers. As a moral doctrine, it has all the right to do so. "Progress became the modus vivendi of criticism (...). It made available a sphere of absolute freedom in the present to the executor of criticism" (p. 110). Absolute freedom is a freedom to exclude. The problem is Trump is its opponent.

\section{Other methodological concerns}

Koselleck was writing this in the time of the Cold War, and saw opposing sides as two moral doctrines that approve the destruction of the other. That is, while absolutist monarchy has established social peace by breaking all its opponents, now everyone wants this power. What Koselleck (1988, p. 18) was saying about the monarch, that "he must subjugate all or no one would be subjugated", is now something that all sides encourage. National and transnational capitals have their own moral doctrines, albeit this is not a black and white issue. If we can register this in the case of Charlottesville, in the media coverage, then we could register a special bias of mediatization. Media are steered by professionalism and audience involvement (Hjarvard 2013, p. 26). News media should objectively present the arguments of both sides through the frame of conflict (de Vreese 2014), and also adapt to the attitude of the audience. Next section will show whether this actually happened.

I will analyse one commercial and one public television news show in the USA in the period from 12 to 19 August 2017. PBS NewsHour is chosen to check whether 
public TV can slow the expansion of commercial logic (Stromback 2008, p. 242). CBS Evening News is chosen because CBS" owner Sumner Redstone is a "switcher" that supported both Democrats and Republicans and is expected to follow the commercial logic of transnational capital. This is important in Charlottesville's case, where there were at least some extreme-right activists with brutal methods of social struggle, with tragic consequences - the death of a young woman. Covering Charlottesville in a professional, balanced way is a super-human challenge, but it is possible. With two different social movements confronted over Innis' monuments as heavy media, a President that embodies the principle of Absolutism and an audience that is not ready to completely support any side, Charlottesville's case seems like a good example of the bias of mediatization. My method is critical and highly qualitative, it is interpretative and multiperspectival in a sense that reads the media texts as embedded in the social, political and economic context (Kellner 1995, p. 4). It is interdisciplinary, meaning that articulation of discourse and its environment is essential for theorizing the interplay that is at the heart of the mediatization process. Therefore, frame analysis should be informed by a theoretical framework that deals with a Habermas' and Kosseleck's political confrontation within public sphere and the social structure supporting it.

\section{Logic of the Enlightenment in Charlottesville}

It was the weekend. This meant decision makers were having a day off. Journalists did not have much guidance and presented the events pretty straightforward. CBS reported it was a "clash between alt-right protesters and counter-demonstrators" and that there were "groups including the KKK and neo-Nazis". Opposing sides fought "with little interference from the police". Trump condemned the "display of hatred, bigotry and violence on many sides" and called for calm and unity. On the first day, this was not questioned. He was the Absolutist who blamed and subjugated all sides. Trump said "there is no place for this kind of violence in America", and there were no political elite to say otherwise. Elite consensus and corporate ownership remained still. Both TV networks included already prepared segments about foreign leaders sending Trump a message to avoid rhetoric that could escalate into violence. If Trump "went too far" against North Korea, why would someone demand from him to do the same against the alt-right activists? PBS showed both sides of the struggle, and relied on the statements by the protesters themselves. The ones who were supporting the taking down of the Confederate statue blamed the White House for giving the licence for "fear and hate", while the right-wing militia member said they "came here in peace, for freedom of speech". Commercial network did not even mediate the reactions of the participants, while PBS chose the militia member as an alt-right representative.

Sunday was a different day. Social and discourse structures were reconnected. CBS asked "was it domestic terrorism"? Trump was criticized for being "too vague" in 
denouncing the white supremacists, but the centre of the show was expectedly the victim that "lost her life protesting hate". Her Facebook comment "If you're not outraged, you're not paying attention" stood against "blood and soil" shouts of the racist crowd. Organizer of the rally accused police for not doing their jobs, while Trump maintained this is not his or Obama's fault, but "has been going on for a long time". PBS reported that members of Trump administration called it an act of racial bigotry, a criminal act, while Senator Orrin Hatch said Trump should "call evil by its name". Other comments suggested Trump's "dance with the devil" maybe have "unleashed the demons" that led to the chaos in Charlottesville. PBS also included the opinion of the other side, that accused the "radical leftists" for shouting "kill all the Nazis" and that "their definition of a Nazi is everyone they politically disagree with". Peter Bergen, CNN Security analyst, maintained there was a rise in the White and Black nationalist attacks, as well as anti-Trump "leftist terrorism", so security threat had "all ideological stripes", even though the right-wing is most severe. That is, because the first day of the event was Saturday, the elites were not ready and their reaction was postponed for Sunday. Saturday was a day without the struggle of national and transnational capital, so the commercial media were not able to comment the event, while public TV covered both sides of the issue.

On Monday, public pressure worked. Trump said "Racism is evil" and condemned the KKK and other hate groups. CBS journalists maintained he was "slow to denounce" the white supremacists. A segment about the murderer revealed he was a "Hitler lover", with an underlining message this kind of "love" is widespread. Transnational capital's logic was working now. PBS was more critical and looked for the shades of grey. First, PBS was dealing with right-wing activists' tactics, considering they got a lot of coverage, but also that both sides made headlines. Both sides will claim victory, "become calcified in their belief" and "outrageous in their rhetoric". PBS also differentiated between domestic terrorism, the growing number of pro-white groups and the legacy of the Civil War. Edward Ayers (University of Richmond) said slavery usually did not play a leading narrative role. Confederacy is pictured as a libertarian defence against the central government, and statues were actually built by sons and daughters of the veterans in the process of mourning. Pure media logic, about family and emotion. That is, Ayers suggests, people see history through "different eyes" and statues can mean different things, but one should put them in the right context in order to completely understand the Southern heritage. PBS was less inclined to dramatize and intensify conflictual discourses, but was more sentimental towards Innis' heavy media.

The most important thing that day was the departure of CEOs from President's Business Councils. They found Trump morally repugnant and this was the last straw. However, Habermas' view about economic power and political powerlessness casts a shadow of a doubt. While CBS reported council's member found Trump's "spirited defence of racism and bigotry unacceptable", PBS suggested there's a socio-economic background to it, rather than ethical. Trump's statement about companies that man- 
ufacture in foreign countries and did not want to bring jobs back highlighted this. It was also found that Amazon is damaging small retailers and its CEO is an owner of Washington Post, which was critical of the President. PBS implied the interests of the transnational capital were the reason for CEOs' departure and not just Trump's behaviour. It is that Trump's Presidency (or should we call it "Absolutism") is creating problems for their transnational businesses. It was the conflict between authority and publicity that was at the heart of Habermas' public sphere theory, and the events in Charlottesville showed this has not changed.

But this is not the highlight of the whole problem. The question of the right-wing extremism could be directly related to the left-wing activism. PBS' source said digital platforms like Google or Twitter were announcing they will stop supporting the right-wing pages. But what these companies were actually doing is silencing the groups that are not right-wing at all. Targets were people who gather war crimes evidence or parody the website of the Chamber of Commerce. Digital platform's discrimination hurts other people more than right-wing extremists. This means there are too many cases where "powerful people get to censor and take speech down". This is not paradoxical if you are aware both sides are neoliberal. Therefore, both sides would like to see left-wing actors out of the picture. Actually, left-wing actors are the only one who can disturb the neoliberal hegemony, while the right-wing populism can only "temporarily suspend" the principle of the free society. This is the kind of populism I would call populism for neoliberalism. It is crucial to highlight that the exclusion of radical right-wing platforms was an excuse to exclude left-wing platforms, too. This was not an issue for Trump and his opponents, because it was in their mutual interest. Only PBS covered it. It was business and not in the public interest.

Therefore, while Trump said both sides are violent and blamed all, according to the Absolutist principle, Trump's critics were also masking corporate wrongdoings behind righteous indignation. There is no clear choice in this. Trump defended all statues, not just of Confederate figures but of other slave owners like George Washington or Thomas Jefferson, the founding fathers. Commercial CBS worried Trump did not show "moral disgust" and invented the "alt-left" violence. PBS tried to understand Trump's enthusiasm for "beautiful statues" in another way. PBS had no doubt KKK was marching in Charlottesville against the social change, but is Trump one of them? Is he hiding his ideology behind the law and order rhetoric? Or he "lacks the imagination" and does not have the "collective memory" of clan's violence? He does claim all those people in Charlottesville were not neo-Nazis, and PBS' poll showed $62 \%$ of people think that statues should remain as historical symbols. The poll also showed the majority was not satisfied with Trump's reaction, but if the media were receiver steered, than the logic should adapt to this paradoxical poll results. Can $62 \%$ of people be Hitler lovers? If Stig Hjarvard is right, and the audience involvement is shaping media logic, then the attitude of the majority of the citizens should change the commercial media's approach. 
After the poll came out, CBS tried a different approach. Now, following Steve Bannon's words, the far right were "clowns", and the Democrats were too focused on the race and identity, instead of economy. CBS reported that Andrew Young, a civil rights icon, said it is "too costly to re-fight the Civil War", but what does that mean? It was reported that a great grandson of a Confederate commander said he is "ashamed of the monument but not Stonewall Jackson himself", without explanation what is the difference between the two. This implied some statue is the biggest problem in the USA. The only choice CBS gave to its audience is a "Holocaust-like memorial" or "removing identity politics" altogether, and both came from African American sources. A frame of conflict, the dramatical "deep and ugly division", seems to be the only media logic construct CBS is able to produce. Intensifying the conflict and creating a black and white issue, while $62 \%$ of citizens did not see it that way, should be interpreted as a sign that the commercial media logic is not that receiver steering. It is corporate foremost.

Usually, populism is understood as a strategy that will criticize other people's symbols and rights but not their own (Bjerre 2016, p. 23). That is, right-wing populists cannot contribute to political progress. However, PBS showed something different. The host interviewed a South Carolina's secessionist and African American nationalist, a White Christian and a Black Muslim, that came together to preserve peace and "collaborate for the public good". The Black nationalist maintained "taking down the statues does not end systematic oppression", nor does it "raise the economic conditions". This is not just a race but a "class issue". He would be happy if the statues were removed, but this is not a priority. White secessionist looked at him and was not happy about it. Nevertheless, he said he has "more in common" with a Black Muslim than with the people from Charlottesville, who made things worse. He still wants to defend the Southern heritage, but not in a racist or neo-Nazi way. This was what $62 \%$ of Americans believe and what commercial media could not report. PBS produced a very consensual worldview without jeopardizing its non-neoliberal and non-racist agenda. On the other hand, CBS chose to support neoliberalism through its progressive attack on the alt-right. But how progressive is it with neoliberalism in the background?

\section{Conclusions}

Commercial media logic showed itself as less committed to the general audience than to the principles of the liberal public sphere of the Enlightenment era. For Habermas, this was an era of economically powerful actors that wanted to translate their power to the political sphere, which brought the French Revolution. The discourse of progress moved the ideal society from distant lands to the future. That way, reality became a temporalized Platonism: things are bad now and it will be fixed soon. The problem is in the feudal past. The absolute ruler is the force against progress and democracy. In the past, there's only exploitation and intolerance. 
Habermas' public sphere was marked not by one-dimensional progress but a dialectic of authority and publicity, a mode of balancing power, a dialogue with the possibilities of compromise. Once this balancing was replaced by colonization, the relationship of the state and the market was not a win-win situation. With a weak state and strong globalization, corporate media were less inclined to balance between powers. Even though Charlottesville is a hard case, it showed commercial media logic as a neoliberal force that is implementing a highly controlled future. In a free society, we cannot plan this. The idea there can be "one best society for everyone" is "incredible" (Nozick 1999, p. 311).

Therefore, the relationship of mediatization to populism is twofold. It is not just the construction of media populism by the national capital's media. It is also embodied by a transnational capital's media bias. That is, both sides imply the other one is fake. Yet, Habermasian framework focuses on interests and relates social to discourse structures. It shows conservative forces as more inclined to national capital and the authority of the President, while progressive forces were more present within transnational capital networks, seeking multicultural utopia, without questioning social contradictions seriously. This highly ambivalent, neoliberalized position of commercial media I have called the bias of mediatization.

We have seen perfectio ideal seeks to shut down not just right-wing paleo-utopias, but any other competitors. PBS' more informative coverage followed Innis' idea of checking the biases, and this made its critical position stronger. CBS' neoliberal approach brought one vision for the world that actually did the same thing as Donald Trump himself: it suspended other discourses. This is not the best solution for the postmodern condition of cultural diversity. The task of political liberalism is the construction of a framework for many times and many utopias. For mediatization research the question is whether this can be a commercial framework. From the critical perspective, I believe the public media such as PBS can actually show a different path for media's institutionalisation.

\section{References}

Balibar E. (2015). Citizenship. Polity Press: Cambridge.

Bjerre H.J. (2016). Freedom of expression in the era of the privatization of reason. Akademisk kvarter, Vol. 14, pp. 12-25.

Bonefeld W. (2017). Strong State and the Free Economy. Rowman \& Littlefield: London.

Chomsky N. (1989). Necessary Illusions. Pluto Press: London.

Couldry N. (2014). Mediatization and the Future of Field Theory. In: K. Lundby (Ed.), Mediatization of Communication. De Gruyter Mouton: Berlin, pp. 227-249.

Curran J. (2011). Media and Democracy. Routledge: London. 
De Vreese C.H. (2014). Mediatization of News: The Role of Journalistic Framing. In: F. Esser, J. Stromback (Eds.), Mediatization of Politics: Understanding the Transformation of Western Democracies. Palgrave MacMillan: New York, pp. 137-156.

Fairclough N. (2018). CDA as Dialectical Reasoning. In: J. Flowerdew, J. Richardson (Eds.), The Routledge Handbook of Critical Discourse Studies. Routledge: London, pp. 13-26.

Friedman M. (1982). Capitalism and Freedom. University of Chicago Press: Chicago.

Habermas J. (1989). The Structural Transformation of the Public Sphere. MIT Press: Cambridge.

Habermas J. (2012). The Crisis of the European Union. Polity Press: Cambridge.

Hayek F. (1998). Law, Legislation and Liberty, Vol. 3: The Political Order of a Free People. Routledge: London.

Hepp A. (2013). Cultures of Mediatization. Polity Press: Cambridge.

Hjarvard S. (2013). Mediatization of Culture and Society. Routledge: London.

Honneth A. (1995). The Struggle for Recognition. MIT Press: Cambridge.

Inglehart R., Norris P. (2016). Trump, Brexit, and the rise of Populism. Paper presented at the $24^{\text {th }}$ World Congress of the International Political Science Association.

Innis H. (2008). The Bias of Communication. University of Toronto Press: Toronto.

Kellner D. (1995). Media Culture. Routledge: London.

Koselleck R. (1988). Critique and Crisis. MIT Press: Cambridge.

Koselleck R. (2002). The Practice of Conceptual History. Stanford University Press: Stanford.

Koselleck R. (2004). Futures Past. Columbia University Press: New York.

Marcuse H. (1969). An Essay on Liberation. Beacon Press: Boston.

Marcuse H. (1972). Counterrevolution and Revolt. Beacon Press: Boston.

Marcuse H. (1991). One-Dimensional Man. Routledge: London.

Mazzoleni G. (2014) Mediatization and Political Populism. In: F. Esser, J. Stromback (Eds.), Mediatization of Politics: Understanding the Transformation of Western Democracies. Palgrave MacMillan: New York, pp. 42-57.

Močnik R. (2017). Beyond fascism? Historical parallels and structural specificities of post-socialism. Tiempo devorado, Vol. 4(1), pp. 146-165.

Nozick R. (1999). Anarchy, State, and Utopia. Blackwell: Oxford.

Peruško Z. (2017). Mediatization: From Structure to Agency (and back again). In: O. Driessens, A. Hepp, S. Hjarvard, G. Bolin (Eds.), Dynamics of Mediatization: Institutional Change and Everyday Transformations in a Digital Age. Palgrave: Basingstoke, pp. 57-85.

Rüstow A. (1980). Freedom and Domination. Princeton University Press: Princeton.

Streeck W. (2011). The crises of democratic capitalism. New Left Review, Vol. 71, pp. 5-29.

Stromback J. (2008). Four phases of mediatization: An analysis of the mediatization of politics. Press/Politics, Vol. 13(3), pp. 228-243.

Van Dijk T. (2018). Socio-Cognitive Discourse Studies. In: J. Flowerdew, J. Richardson (Eds.), The Routledge Handbook of Critical Discourse Studies. Routledge: London, pp. 26-44. 